\title{
La Virgen de Guadalupe: \\ Personaje nexo entre el cine \\ mexicano y la Historia
}

\section{Alma Delia Zamorano Rojas ${ }^{1}$ \\ azamoran@up.edu.mx}

ORCID: https://orcid.org/0000-0002-7043-4977
La Virgen de Guadalupe: Nexus

Character Between Mexican Cinema and History

\section{Resumen}

Este trabajo tiene como objetivo realizar un recorrido en la filmografía mexicana recuperando al personaje de la Virgen morena del Tepeyac. Partiendo de la clasificación del cine histórico de Robert Rosenstone en su obra La historia en el cine: el cine sobre la Historia (2014), se pretende analizar los nexos entre el cine Palabras clave: Virgen de Guadalupe, cine mexicano, historia, identidad, imaginario cinematográfico.

\section{Abstract}

The objective of this work is to make a film journey between the connections of the cinema and the history where the Virgen morena del Tepeyac has been present. Based on the classification of historic cinema proposed by Robert Rosenstone in his work History in the cinema: cinema in history (2014), the article analyses the y la historia con motivo de esta protagonista cinematográfica, la cual se ha hecho presente desde 1917 hasta 2009, algunas veces como intérprete, otras como acompañante y muchas más como intercesora, se ha hecho recurrente a través de la representación del milagro guadalupano en el imaginario cinematográfico nacional.

Keywords: Virgin of Guadalupe, Mexican cinema, identity, cinematographic imagery. México. 


\section{Introducción}

El cine con temática religiosa inició con la llegada del cinematógrafo a México -Entrada a una boda en una iglesia (1899) de Carlos Mongrad, Saliendo de la catedral (1900) de Salvador Toscano y Salida de misa de 12 de la Parroquia de Orizaba (1900) de los hermanos Becerril, entre otras-, sin embargo, el más destacado fue el mito de la Virgen de Guadalupe, $-E l$ grito de Dolores (1908) de Felipe de Jesús Haro-, que además de expresar la espiritualidad del mexicano se conformó en vestigio de su identidad.

Partiendo de la propuesta de Robert Rosenstone sobre cine histórico en su obra La historia en el cine: el cine sobre la Historia (2014), se pretenden analizar los nexos entre el cine y la historia, recorriendo la filmografía mexicana y recuperando al personaje de la Virgen de Guadalupe, presente desde 1917 hasta 2009. Se parte de dos premisas: la representación del milagro guadalupano es un elemento imprescindible en los argumentos cinematográficos, no importando la trama de las cintas ni su año de realización; y que los nexos entre cine e historia se han realizado desde la ficción que se sirve de la historia para crear sus argumentos.

Para ello, se presentan varios momentos históricos en los que el mito guadalupano fue fundamental para la consolidación de la identidad mexicana, subrayando su origen, alcance y trascendencia en diferentes épocas.

Posteriormente, se desarrollan los vínculos entre cine, historia e identidad mexicanos, para llegar a una definición de cine histórico y a la propuesta de Rosenstone en torno a éste, misma que fungirá como metodología y eje principal del análisis de los filmes que integran el corpus.

Una vez establecidos el contexto y el marco teórico, se analizarán diecinueve filmes ${ }^{2}$ de manera cronológica abordando diferentes etapas de la filmografía mexicana. El análisis incluirá características de las producciones en torno a la Virgen de Guadalupe, tramas recurrentes y construcciones en relación con la historia.

\section{La Virgen de Guadalupe: Cruces y nexos con la historia}

El mito de la aparición de la Virgen de Guadalupe data de 1531, diez años después de la llamada Conquista de México con la caída de Tenochtitlán. Sin embargo, a pesar de una incipiente mezcla racial, el mestizaje cultural

2 De los 19 títulos referidos se tuvo acceso a 15 filmes de los que se hacen los comentarios y referencias en el trabajo. Las películas que no se pudieron ver fueron: La virgen de Guadalupe (1918), Bodas de plata de la Virgen de Guadalupe (1920), Documental sobre la Basílica (1922) y la Revista cinematográfica El Universal (1924). 
se desarrolló lentamente, pues los españoles no entendían el valor cultural indígena e intentaban imponerse; como padres amorosos y buenos $3 / 4$ misioneros $3 / 4$, y como hombres civiles y militares que hacían uso de la fuerza. Los nativos veían morir tradiciones, dioses y costumbres, y los españoles advertían idolatría y pecado en ellos. Parecían dos mundos irreconciliables hasta el mito de la aparición Guadalupana, el cual coadyuvó a unificar a la naciente patria:

El inicio del culto guadalupano en las primeras décadas del siglo XVI, en un momento en que era necesario contar con un vigoroso elemento catalizador de la población novohispana significó un apoyo singular a la labor unificadora [...] Conforme la nación mexicana fue formándose, el culto guadalupano fue creciendo [...]. Conforme México adquiría su mayoría de edad, conforme el espíritu y la conciencia de los mexicanos se fueron haciendo más firmes y seguros, la veneración a la imagen de Guadalupe, la consideración de que su culto estaba ligado a nuestra personalidad fue acentuándose (De la Torre, 1982, p. 22).

Al reflexionar sobre los posibles orígenes del mito se pueden mencionar dos antecedentes: la Virgen morena de la Villa de Guadalupe en Cáceres, Extremadura, España, hallada a finales del siglo XII por Gil Cordero en el río Guadalupe, y traída por Hernán Cortés como estandarte en su expedición hasta Tenochtitlán. Y, por otro lado, la diosa náhuatl Coatlicue Tonantzin, ${ }^{3}$ adorada en el cerro del Tepeyac.

Como una hibridación de ambas historias nace el mito de las apariciones de la Virgen de Guadalupe, las cuales son narradas por primera vez en el Nican Mopohua, ${ }^{4}$ texto literario que cuenta las cinco manifestaciones de María de Guadalupe y la estampación de su imagen en una tilma en diciembre de 1531, a diez años de haber caído la Gran Tenochtitlán bajo el dominio español.

A partir de entonces, serán los cruces entre la historia y la imagen de la Virgen morena los que construirán su mitología. Durante la época de

3

Deidad prehispánica vinculada con la fertilidad y la maternidad en la cultura mexica.

El Nican Mopohua narra las cinco apariciones de Santa María de Guadalupe y la estampación de su imagen en una tilma de hilo de maguey de las que comúnmente usan los indios, ocurrido todo ello en el mes de diciembre de 1531, a diez años de haber caído la Gran Tenochtitlán bajo el dominio español. Por la belleza de su prosa, a menudo salpicada de expresiones dulces e imaginativas, podemos clasificar este opúsculo como un relato poético. 
la colonia fueron varios los documentos históricos que mencionaron un intenso debate entre autoridades eclesiásticas y cronistas acerca de la aparición y veneración de la Virgen de Guadalupe en el Tepeyac y sus milagros, pudiendo calificar este periodo de antiaparicionista. ${ }^{5}$

Después se construyó el mito de la toma de la imagen como estandarte por el cura Miguel Hidalgo y Costilla para iniciar el movimiento autonomista del país con la arenga: "¡Viva la Virgen de Guadalupe!, ¡Muera el mal gobierno!, ¡Viva Fernando VII!”, que también presenció el decreto de José María Morelos y Pavón:

Por los singulares, especiales e innumerables favores que le debemos a María santísima en su imagen de Guadalupe, patrona defensora y distinguida emperatriz de este reino estamos obligados a tributarle todo nuestro culto y adoración, manifestando nuestro reconocimiento, nuestra devoción y confianza [...] Por tanto mando que en todos los pueblos del reino, especialmente los del Sud (sic.) de esta América septentrional se continúe la devoción de celebrar una misa el día 12 de cada mes, en honra y gloria de la Santísima Virgen de Guadalupe... (Senado, 2010, p. 234).

Asimismo, Agustín de Iturbide la recordó para crear la Orden Imperial de Guadalupe, como un reconocimiento por los beneficios ofrecidos a la lucha independentista y por su intercesión como madre de todos los mexicanos. Véase el texto de Francisco de la Maza (1953) en cuyo primer capítulo que aborda el periodo colonial, se hace notar el escepticismo para aceptar la existencia del milagro guadalupano, lo que ocasionó que en este periodo surgieran más textos escépticos que testimonios de milagros, pues se pensaba que el culto guadalupano se había apoderado de los indios causando en ellos idolatría. "A pesar de los ataques de frailes, virreyes y cronistas, de los 'intelectuales' de entonces, el culto guadalupano crecía pujante en el pueblo, de donde dimana toda fuerza y toda 'verdad' religiosa. Crecía en los indios, como Tonantzin o como Guadalupe; en los criollos, como señal distintiva y propia; en los habitantes de la amarga ciudad de México. Se nutría del sentimiento indígena, mestizo y criollo, que comenzaba a ver algo propio, no prestado y por eso triunfó del ambiente de negación en que creció durante el siglo XVI. La decepción de los criollos de sentirse 'colonos', es decir, de que todo viniese 'de allá' y nada hubiese 'de aquí', comenzó a sentir suya esta devoción, este milagro de origen netamente indígena, pero de floración absolutamente criolla, nueva y sin raíces europeas, de México solamente" (p. 28). 
En la segunda mitad del siglo XIX, el ícono continúa acompañando al pueblo de México con Maximiliano de Habsburgo, quien conserva al catolicismo como la religión oficial del II Imperio mexicano, pese al establecimiento de la libertad de cultos.

Tendrán que pasar algunos años para que se enarbole nuevamente la imagen con ideales políticos y religiosos durante la Revolución, ahí el zapatismo la utilizó junto al lema "Tierra y libertad". En la postrevolución se convirtió en símbolo de protesta, cuando Plutarco Elías Calles atente contra los privilegios de la Iglesia durante la guerra cristera. ${ }^{6}$

Las rasgaduras que sufrió la imagen de la Virgen de Guadalupe se consideraron un atentado de tal magnitud que llevó al canónigo a declarar que con esto el socialismo se suicidó pretendiendo destruir la religión y supo el mundo que para México hay algo que vale más que su bandera, la Virgen de Guadalupe; que tocarla es tocar el alma nacional y que morir por ella es morir por Dios y por la patria (Vaca, 2016, p. 126).

Se ha esbozado brevemente el recorrido que la imagen de la Virgen de Guadalupe ha tenido en la historia de México, consolidándose en mito simbólico del nacionalismo y la identidad mexicana, pues la mujer de luna y estrellas con rasgos indígenas y encargo cristiano se transformó en un personaje con mensaje político y social, emblemático para México.

El culto de Nuestra señora de Guadalupe, el guadalupanismo, esa sacralización admirable está por encima de la historia, de la ciencia, de la razón, porque finalmente no es la invención de una Iglesia, sino la del propio pueblo. Se trata pues de algo sagrado y lo sostiene la propia historia [...] (De la Torre, 1982, p. 188).

Por ello, la imagen Guadalupana ha sido protagonista entrañable en los procesos sociales de la nación, teniendo una representación sobresaliente a través del cine, constituyéndose en tema atemporal hasta la actualidad, construyendo tramas sobre los milagros guadalupanos a trateros se sumó a los tabúes del cine mexicano. La revolución fue el primero, mientras no hiriese susceptibilidades de los que están en el poder, y los cristeros aumentaban el acervo; este último será y continuará siendo el tema al cual el gobierno ve con menos buenos ojos. Se continuaba la tradición iniciada en el régimen de Carranza de voltear los ojos a la realidad; este era un tema al que aparentemente jamás se debía acercar el cine mexicano" (p. 85). 
vés de un recurrente retorno al mito iniciático: su aparición al indio Juan Diego, y con ello, el vínculo perpetuo con el pueblo mexicano.

Diez años después de tomada la ciudad de México, se suspendió la guerra y hubo paz en los pueblos, así como empezó a brotar la fe, el conocimiento del verdadero Dios, por quien se vive. A la sazón, en el año de mil quinientos treinta y uno, a pocos días del mes de diciembre, sucedió que había un pobre indio, de nombre Juan Diego, según se dice, natural de Cuautitlán. Tocante a las cosas espirituales, aún todo pertenecía a Tlatelolco. Era sábado, muy de madrugada, y venía en pos del culto divino y de sus mandados. Al llegar junto al cerrillo llamado Tepeyac, amanecía; y oyó cantar arriba del cerrillo: semejaba canto de varios pájaros preciosos; callaban a ratos las voces de los cantores; y parecía que el monte les respondía. Su canto, muy suave y deleitoso, sobrepujaba al del coyoltototl y del tzinizcan y de otros pájaros lindos que cantan. Se paró Juan Diego a ver y dijo para sí: “¿Por ventura soy digno de lo que oigo?, ¿quizás sueño?, ¿me levanto de dormir?, ¿dónde estoy?, ¿acaso en el paraíso terrenal, que dejaron dicho los viejos, nuestros mayores?, ¿acaso ya en el cielo?" Estaba viendo hacia el oriente, arriba del cerrillo, de donde procedía el precioso canto celestial, y así que cesó repentinamente y se hizo el silencio, oyó que le llamaban de arriba del cerrillo y le decían: "Juanito, Juan Dieguito". Luego se atrevió a ir a donde le llamaban; no se sobresaltó un punto; al contrario, muy contento, fue subiendo el cerrillo, a ver de dónde le llamaban. Cuando llegó a la cumbre, vio a una señora, que estaba allí de pie y que le dijo que se acercara. Llegado a su presencia se maravilló mucho de su sobrehumana grandeza: su vestidura era radiante como el sol; el risco en que posaba su planta, flechado por los resplandores, semejaba una ajorca de piedras preciosas y relumbraba la tierra como el arco iris. Los mezquites, nopales y otras diferentes hierbecillas que allí se suelen dar, parecían de esmeralda; su follaje, finas turquesas; y sus ramas y espinas brillaban como el oro. Se inclinó delante de ella y oyó su palabra, muy blanda y cortés, cual de quien atrae y estima mucho. Ella le dijo: "Juanito, el más pequeño de mis hijos, ¿a dónde vas?" Él respondió: "Señora y niña mía, tengo que llegar a tu casa de México Tlatelolco, a seguir las cosas divinas, que nos dan y enseñan nuestros sacerdotes, delegados de Nuestro Señor". Ella luego le habló y le descubrió su santa voluntad y le dijo: "Sabe y ten entendido, tú el más pequeño de mis hijos, que soy la siempre Virgen Santa María, Madre del verdadero Dios por quien se vive; del creador que sabe dónde está todo; Señor del cielo y 
de la tierra. Deseo vivamente que se me erija aquí un templo, para en él mostrar y dar todo mi amor, compasión, auxilio y defensa, pues yo soy vuestra piadosa madre; a ti, a todos vosotros juntos los moradores de esta tierra y a los demás amadores míos que me invoquen y en mí confíen; oír allí sus lamentos, y remediar todas sus miserias, penas y dolores. Y para realizar lo que mi clemencia pretende, ve al palacio del obispo de México y le dirás cómo yo te envío a manifestarle lo que mucho deseo, que aquí en el llano me edifique un templo: le contarás puntualmente cuanto has visto y admirado, y lo que has oído... (Centro de Estudios Guadalupanos, 1980, p. 29).

\section{Cine / historia / identidad}

Para comprender la identidad guadalupana en el cine mexicano, habrá que retomar la historia de este importante medio de comunicación desde 1896, máquina de entretenimiento que compensó las necesidades de evasión y ensoñación de varias generaciones en el país, y aun sin una intención política definió y transmitió ideas que configuraron el rostro de la identidad mexicana en millones de mujeres, hombres y niños, quienes a través de cientos de películas establecieron una relación de pertenencia a un colectivo denominado México.

Captaron a la gente en sus paseos dominicales en las alamedas pueblerinas, o a la salida de la misa de las doce, bodas, desfiles, jarabes tapatíos bailados en la calle, el tradicional paseo cuaresmeño de Santa Anita, escenas de charrería en una hacienda (De los Reyes, 2011, p. 20).

En este sentido, la relación del cine con la historia ha tenido cruces en el ámbito teórico, entendiéndose de diversas formas: al hacer referencia al cine como un hecho cultural de su época, producto de la sociedad, todo filme es histórico per se; al mostrar elementos espacio temporales que fungen como una fuente para el estudio del siglo XX. Y, por otra parte, también se encuentra lo que se podría denominar la historia filmada $3 / 4 \mathrm{a}$ través de noticieros y documentales $3 / 4$, eventos captados por la cámara en el momento preciso. Sin embargo, estas relaciones adquieren importancia al intentar concebir una definición de cine histórico: la vinculación de la historia con la ficción.

Concepto mal acuñado, puesto que, todo film es potencialmente histórico, en tanto que es el producto de una sociedad determinada y, por consiguiente, una fuente para el estudio de esa sociedad. Entonces, 
sería mejor hablar de cine sobre historia o alrededor de la historia, pero, aunque semánticamente erróneo, el término "cine histórico" está comúnmente aceptado para referimos a las películas centradas en el pasado (Bornstein, 1991, p. 278).

Partiendo de este concepto, han sido muchos los estudiosos que han intentado clasificarlo, desde Siegfried Kracauer (1047) con De Caligari a Hitler, pasando por los aportes de Marc Ferro y Pierre Sorlin, y los trabajos de historiadores como Stephen Dolezel, Kenneth Short, Paul Smith, Charles Musser, Martín A. Jackson y Robert Rosenstone, quienes han propuesto diferentes posturas para el análisis de películas con temas históricos, así como la relectura de infinidad de filmes para la comprensión de hechos y acontecimientos de determinadas épocas.

En el caso del mito de las apariciones Guadalupanas, es necesario revisar la representación de sucesos y personajes de la historia de México que se ha vinculado al imaginario social, para conformar la historia oficial y la Historia en un sentido amplio. Según Enrique Florescano, los mitos de México han sido reproducidos para constituir una historia del pasado acorde con las condiciones socio-políticas del presente.

El pasado, antes que conocimiento especulativo acerca del desarrollo de los seres humanos, fue memoria práctica de lo vivido y heredado, aplicada a la supervivencia del grupo. Sobrevivir fue durante siglos la meta singular de la mayoría de los seres humanos. De esa experiencia vital nacieron las artes dedicadas a recolectar la memoria del grupo, los procedimientos para almacenarla en medios perdurables y los artefactos para heredarla a las generaciones futuras (Florescano, 1999, p. 35).

Así, el cine mexicano ha sido un arte de alcance y penetración cultural, así como un medio de información, creador y recreador de la historia de México, pues según Béjar y Rosales, la historia implica una comprensión nueva de los sucesos que se transforman en acontecimientos a través de la narrativa cinematográfica y, en este caso, la Virgen de Guadalupe ha sido uno de los personajes que ha atravesado la historia de México junto a la historia del cine mexicano.

¿Cuáles son los momentos claves del devenir mexicano que habría que revisitar? ¿Hasta dónde es necesario aventurarse? La simbología tradicional incluye a Netzahualcóyotl, Moctezuma, Cuauhtémoc, Cortés, doña Marina [...], los frailes y virreyes, los precursores ideológicos de la independencia, los padres y madres de la patria, los cau- 
dillos, la tipificación de personajes populares y estereotipos... (Béjar y Rosales, 1999, p. 16).

En este sentido, la representación del mito guadalupano en el cine es tierra fértil para la creación de una memoria colectiva sobre la historia de México, pues "una reconstrucción del pasado ajusta la imagen de viejos eventos a las creencias y necesidades espirituales del presente" (Halbwash, 1950, p. 18).

Asimismo, la identidad nacional se conforma por las "memorias históricas compartidas que corresponden a los mitos, a memorias de un pasado común [...] que participan en una memoria colectiva" (Páez, et. al. 2000 , p. 33). Por ello resulta interesante la relación que guarda el cine como posibilidad narrativa al acercarse a la Historia, pues:

No basta considerar al cine como algo que afirma y confirma la veracidad de un acontecimiento, porque hay mucho más que eso en cada imagen del pasado que se produce. En ella están en juego mecanismos sociales particulares: voluntades de representación, efectos involuntarios de la imagen, pequeñas y grandes estrategias de poder, algunas veces políticas o simplemente comerciales; elaboraciones estéticas, instancias que ameritan, cada una por sí mismas, la atención del historiador (De Orellana, 1991, p. 16).

El cine ha creado representaciones simbólicas muy prolíficas a propósito del mito de la Guadalupana en la sociedad mexicana, teniendo como eje la recreación de la Historia y la narración mitificada de la Historia.

La historia escrita convencional es [...] tan lineal y limitada que es incapaz de mostrar el complejo y multidimensional mundo de los seres humanos. Sólo las películas -capaces de incorporar imágenes y sonidos, de acelerar y reducir el tiempo y de crear elipsis-, pueden aproximamos a la vida real, la experiencia cotidiana de las ideas, palabras, imágenes, preocupaciones, distracciones, ilusiones, motivaciones conscientes e inconscientes y emociones. Únicamente el cine nos proporciona una adecuada reconstrucción de cómo las gentes del pasado vieron, entendieron y vivieron sus vidas (Rosenstone, 1997, p. 31).

A pesar de que dentro del cine existen varios modelos de clasificación de películas históricas, como las categorías utilizadas por la crítica cinematográfica de los años sesenta en donde se habla del cine clásico, el documental y el cine moderno, respectivamente. El aporte de teóricos como 
Stephen Dolezel, Martín A. Jackson o Robert Rosenstone -retomando a Marc Ferro y a Pierre Sorlin $-{ }^{7}$ es que reconocen que existen estos modos de pensar y representar la historia de manera audiovisual.

Las películas plantean a los historiadores un desafío que aún no ha sido afrontado: el reto de pensar en cómo utilizar todas las capacidades del medio para informar, yuxtaponer imágenes y palabras y, quizá, crear estructuras analíticas visuales [...] El cine ofrece nuevas posibilidades de representar la historia, posibilidades que podrían ayudar a la narración histórica a retomar el poder que tuvo en la época en que estaba más unida a la imaginación literaria (Rosenstone, 1997, p. 40).

Asimismo, otro estudio digno de ser citado es el de José María Caparrós, quien parte de la más antigua tradición que distingue entre filmes de ficción o películas argumentales (fiction films o feature films, en la terminología inglesa) y filmes que no son de ficción (non-fiction films). Caparrós ordena estas amplias categorías dividiendo estos últimos en Noticiarios y Documentales, en donde cabrían Reportajes, Actualidades, Filmes didácticos y Filmes de montaje. Mientras que los filmes de ficción son a su vez clasificados en Filmes de reconstrucción histórica, Filmes de ficción histórica y Filmes de reconstitución histórica.

No parece [...] que el hecho de establecer una clasificación suponga admitir la existencia de fronteras [...] No se trata de separar; sino que, como existen diferencias entre diversos tipos de películas, puede resultar útil conocer en qué consisten tales diferencias. Aun así, en 1982 el profesor Denis Richet se planteó la siguiente cuestión antes de exponer los tres tipos de filmes históricos que él diferenciaba: “¿En qué medida y de qué modo puede la Historia beneficiarse de la ayuda

Jorge Lozano (2018) afirma que: "Ferro (1995), historiador de la llamada Escuela de los annales y autor de varias publicaciones y documentales didácticos desde los años sesenta y setenta, ya había afirmado que las obras cinematográficas, incluidas las de ficción, son una suerte de agentes de la historia que implícitamente reflejan la mentalidad de la época y de los realizadores" (p. 224). Mientras que para "Pierre Sorlin (1985), una cosa es reconstituir una época, es decir, crear una época que la evoque, y otra reconstruir un hecho, en el que se re-crea de manera supuestamente fidedigna lo que ocurrió en un tiempo y lugar determinados [...] las obras cinematográficas que reconstituyen el pasado, se refieren más a cómo era o es la sociedad que las ha realizado, a su contexto, que al hecho histórico o referente que aparentan reconstruir" (p. 223). 
fílmica?". Pienso que éste puede ser un buen punto de partida para explicar los posteriores criterios de clasificación, dentro de las convenciones metodológicas... (Caparrós, s.f.).

Respecto a la metodología, se parte de la clasificación realizada por Robert Rosenstone en La historia en el cine: el cine sobre la Historia (2014), quien manifiesta que el cine -como documento histórico-, puede ser abordado a través de tres tipologías: la historia como drama, como experimentación y como documental; siendo la más común el drama histórico.

Esta clasificación permite analizar los temas y pasajes históricos referidos en las obras que hacen alusión al personaje de la Virgen de Guadalupe y lograr su clasificación en cualquiera de las categorías, matizando los argumentos con elementos de la historia.

Es necesario apuntar que, -como ha mencionado Rosenstone- al revisar una película que aborda un hecho histórico, lo importante es juzgar la invención que lleva a cabo de la propia historia, pues es la clave para entender "la historia como relato filmado y, por ello, el más controvertido" (Rosenstone, 2014, p. 57). Si es posible encontrar un mecanismo para entender y juzgar la invención de una película, este permitirá que las alteraciones que se den en esa historia sean diferentes a la historia oficial.

La primera clasificación, el filme dramático o la historia como drama, propone:

Si uno habla de films históricos, la mayoría de las veces se piensa en los dramas históricos. Estas películas han estado presentes en el cine desde su creación y han sido realizadas en todos los lugares -Estados Unidos, Francia, Italia, Japón, China, Rusia, la India-, donde se han creado industrias cinematográficas. Algunas de las películas más famosas son históricas, o por lo menos sitúan su acción en el pasado (Rosenstone, 2014, p. 47).

En esta categoría se incluyen dramas situados en el pasado que han creado una falsa mirada sobre el cine histórico, debido a los "errores" de la puesta en escena. "La diégesis histórica que construyen este tipo de películas puede ser considerado como un equivalente al material empírico y documental aportado por la historia escrita" (Garrido, 1990, p. 30).

Rosenstone aporta los elementos del relato reconocibles en la construcción de una falsa historicidad: la historia se toma como relato, que se crea con individualidades y ofrece una visión cerrada del pasado conformándose en una dramatización de la historia; muestra la historia como 
proceso y proporciona una mirada a cada época histórica a través de la puesta en escena (Rosenstone, 2014, p. 47).

Mientras tanto, el filme histórico como documento es catalogado como innovador, con orígenes en los documentales sociales de los años treinta en Estados Unidos, aunado a reportajes de la Segunda Guerra Mundial.

Su estructura más común es la de superponer la explicación de un narrador (y/o testigos o especialistas) a una serie de imágenes actuales de lugares históricos junto con fotogramas de documentales, noticiarios, fotos, dibujos, pinturas, gráficos y portadas de periódicos de la época. Los historiadores conceden más crédito a este tipo de film que a los de ficción porque parece más cercano al espíritu y los usos de la historia escrita. Da la sensación de ofrecer "los hechos" y una explicación racional de los mismos. Pero uno de los grandes problemas de los documentales radica, justamente, en el uso de material histórico. Pero todas esas fotografías y tomas antiguas están impregnadas de nostalgia. Se nos dice que a través de dichos materiales podemos ver y, presumiblemente, sentir lo que la gente de una época vio y sintió (Rosenstone, 1997, p. 48).

En éste se agrupan películas históricas con personajes y eventos que pueden ser documentados. Estudiosos afirman que este formato es de estilo monográfico y aunque pareciera más veraz o riguroso, en realidad se enfrenta al problema de las fuentes históricas utilizadas en sus indagaciones.

Tratan al espectador de forma autoritaria, dando la sensación de que su acceso privilegiado a lo que se muestra es una prueba implícita de la corrección en la argumentación y que por limitarse 'solo a los hechos' las conclusiones (implícitas o no) son incontrovertibles, al estilo de lo que hacía el cinema-verité (Garrido, 1990, p. 29).

Finalmente, Rosenstone propone visualizar la historia como experimentación, concepto que comprende gran variedad de formas cinematográficas que se alejan del sentido estético de Hollywood mezclando estilos narrativos en historias del pasado "no sólo por los temas que tratan sino por cómo recrean el pasado. Todos combaten los códigos de representación de los filmes tradicionales y, en definitiva, todos rechazan la consideración de la pantalla como una límpida ventana a un mundo real" (Rosenstone, 1997, p. 49). 
Estos filmes crean reconstrucciones históricas con personajes ficticios, aunque contextualizados en eventos documentados y como formas alternativas en la narrativa. Al no aproximarse directamente al pasado, la experimentación ofrece miradas parciales de acontecimientos históricos desde el presente.

Aunado a las categorías de Rosenstone, los conceptos de cultura, nacionalismo e identidad también permiten el acercamiento a la historia de México enfrentando problemas de la representación, consecuencia de imágenes acumuladas en el tiempo, por ello:

¿De qué memorias, símbolos e instituciones disponemos? ¿Hemos renunciado como colectividad a imaginar futuros deseables? ¿Es posible conjugar el respeto a la diversidad de porvenires en contra de la uniformidad de un futuro común? ¿Qué ideas y proyectos se han formulado en las décadas recientes? ¿Qué sentido tiene renovar símbolos, tradiciones, experiencias, sueños y deseos? (Béjar y Rosales, 1999, p. 58).

México y la Virgen de Guadalupe tienen implicaciones emotivas y éticas para la identidad que asume ideas configuradas en relatos, imágenes, símbolos, discursos, personajes e instituciones que se han fusionado en índices, íconos, emblemas y signos de una realidad social dotada de historicidad, cifrada en temporalidades y espacialidades.

Pero ¿Qué historias ha reconstruido el cine mexicano? ¿Tienen un afán de identificación? En México, las conmemoraciones del bicentenario de la Independencia y el centenario de la Revolución, produjeron un cine con pasajes y personajes históricos desde miradas inéditas e imprecisiones graves, ejemplo de ello son películas como Hidalgo, la historia jamás contada (2010, Antonio Serrano) o Morelos (2012, Antonio Serrano), pues llevar al cine temas históricos significa un reto por intentar producir y ambientar lo que ya no existe; porque las oficinas de gobierno están atentas a quien reescriba la historia -principalmente en los medios-, y por la percepción en la industria de que al público no le interesan estos temas.

\section{Historia y milagros en el cine mudo}

En 1917 José Manuel Ramos y Carlos González realizaron la primera cinta con temática guadalupana, Tepeyac ${ }^{8}$ que recrea la aparición de la Virgen

Tepeyac fue rescatada por el historiador Aurelio de los Reyes y restaurada por la Filmoteca de la UNAM. Ahora puede ser consultada en línea, dividida en seis capítulos en https://www.filmoteca.unam.mx/cinelinea/html/tepeyac.html Existe un expediente 
con un guión sobre un joven que marchó a Europa en una comisión del gobierno, cuyo barco fue hundido por un submarino. Su novia preocupada -mientras esperaba noticias-, leyó el relato de las apariciones, en donde un fraile salva a unos indígenas idólatras y los bautiza. A Juan Diego -uno de ellos-, la Virgen se le apareció tres veces para pedirle la construcción de un templo, haciendo florecer rosas en invierno y grabó su imagen en la tilma del indígena para que convenciera al arzobispo.

Al acabar el relato, la muchacha duerme y al despertar su novio se ha salvado. Después juntos fueron a dar gracias a la Virgen.

De entre los filmes que han logrado arribar con vida al fin de siglo destaca Tepeyac, la primera de las dos únicas producciones de la compañía Films Colonial. Resulta difícil creerlo, pero esta película es obra de un grupo de bohemios que un buen día, sin tener mucho conocimiento sobre la materia, decidieron hacer una película para matar el aburrimiento. El resultado, por demás interesante, presenta la primera aparición del tema guadalupano en la cinematografía nacional. Por su duración es hoy en día el largometraje de ficción más antiguo que se conserva del cine mudo mexicano (Películas del cine mexicano, 2011).

De acuerdo con el argumento, la historia articula una narrativa de ficción en torno al tema de dos jóvenes enamorados que se separan, pues él debe atender asuntos en Europa cuando su barco es alcanzado por un submarino (entendido en el contexto de la Primera Guerra Mundial) desconociéndose su paradero.

En el filme se entreteje la subtrama del mito Guadalupano, pues la joven lee un relato de las apariciones de la Virgen a Juan Diego y en eso obra el milagro. Por ello este filme puede vislumbrarse como historia dramatizada, pues se apela a la apología de la Virgen dentro de una historia ficticia.

No es necesario narrar al lector como ocurrieron las escenas de la aparición de María, con las consiguientes visitas de Juan Diego al arzobispo de México. El hecho es muy conocido y en la película se siguió fielmente la tradición [...] En la cinta aparece el estandarte auténtico que llevó el Cura Hidalgo la madrugada del 16 de septiembre de 1810, al iniciar la guerra de Independencia y que se empleó en el film, gracias a la amabilidad de la dirección del Museo Nacional de Historia y Arqueología. (Dávalos y Flores, 2013, p. 62).

amplio y completo de la película en el Centro de Documentación de la Cineteca Nacional con la clasificación A-04207. 
En 1918, el estadounidense Geo Wrigth llevó a cabo el mediometraje La Virgen de Guadalupe, ${ }^{9}$ que conjuntó ocho cortos de la serie Escenas maravillosas de México, filmadas en la Basílica de Guadalupe y con el apoyo de Antonio Paredes, vicario del recinto. La sinopsis de la película sintetizaba: "Recomendada por el vicario de la Iglesia católica mexicana debía ser una piadosa versión de la leyenda de la Virgen de Guadalupe a través de su santuario, retablos y pinturas" (Viñas, 2005, p. 538).

De acuerdo con el criterio de Rosenstone, este mediometraje, más cercano al trabajo documental, puede ser encasillado como película histórica pues se estructura con un narrador que va explicado los acontecimientos y su desarrollo -en este caso las apariciones de la Guadalupana y el establecimiento de la Basílica en su honor.

En 1920 se realizó el documental Bodas de plata de la Virgen de Guadalupe. Moisés Viñas se refiere a él como: "Se dijo que aparecían todos los eclesiásticos que asistieron a la celebración" (Viñas, 2005, p. 71). La película fue producida por Martínez y Compañía, y por su contenido se infiere que fue un reportaje sobre la festividad, por lo que se puede categorizar como cine histórico documental. ${ }^{10}$

En 1922, la compañía alemana Hallman se interesó en realizar un documental turístico y costumbrista sobre Xochimilco y la Basílica de Guadalupe, teniendo interés en el atrio, interiores y retablos. Aunque existe poca información sobre esta cinta, por el tono de su abordaje se acerca más al filme histórico, recuperando aspectos del mito de la aparición de la Virgen en el cerro del Tepeyac.

Otro filme de estos años apareció en la Revista cinematográfica de El Universal, que en su número 2 -correspondiente al martes 16 de diciembre de 1924-, presentaba de ese mismo año, El pueblo mexicano acude fervoroso a rendir culto a la Virgen india con fotografía y dirección de Víctor Ruiz Sandoval (De los Reyes, 2000, p. 11). Aunque sólo se hizo la

9

10 la coronación de la Virgen de Guadalupe. Aurelio De los Reyes (1993) afirmaba sobre
este suceso en relación con el movimiento cristero: "Desde el mes de octubre, a raíz de
la conmemoración guadalupana, se iniciaron declaraciones intermitentes contra cual-
quier forma de sindicalismo que no fuera el católico. Pronto pasaron a la acción al crear
sindicatos católicos en el Distrito Federal y en el interior del país, así como cajas rurales
para financiar a nuevos pequeños propietarios agrícolas patrocinados por la Iglesia,
para limitar y detener el reparto agrario". (p. 345).

De esta película se encuentra un amplio expediente en el Centro de Documentación de Cineteca Nacional con el número A-03200.

El 12 de octubre de 1920 se realizó la celebración del Vigésimo quinto aniversario de 
mención de este noticiero, por el tono del mismo podría ser inscrito en la categoría de documental histórico.

Un año después, William P. S. Earle filmó El milagro de la guadalupana, con las actuaciones de Celia Montalbán, Boie May y Guillermo Nemer. Esta versión relata la historia de un joven incrédulo y disipado que se enamora de una muchacha devota, y un día al conducir ebrio vuelca su auto y queda paralítico. La joven se salva porque toma la cruz de su collar en el momento del accidente. Tiempo después, ella y un sacerdote visitan al joven y le narran las apariciones de la Virgen a Juan Diego. Ante la imagen sagrada, el muchacho camina, recupera la fe y va con su novia en peregrinación.

Ciertamente no es un engaño, la verdad la forjamos a base de obstinación, pasión y fe. Cuando el hombre quiere creer algo, lo cree de verdad y [el pueblo de México] necesitaba creer en el milagro. La gran devoción que le tiene nuestro pueblo a la venerada imagen la podemos entender también si miramos en los antecedentes prehispánicos la existencia de la Diosa Tonantzin, que en náhuatl significa "nuestra venerada madre" la cual es una diosa de la mitología azteca (Molina, 2010).

El abordaje realizado es a través del filme dramático, pues gran parte del protagonismo recae sobre el indio Juan Diego.

Un nativo mexicano fue elegido para transformar [...] el caos y la división de la conquista en una nación nueva, unida y pujante. Esto hizo de él el apóstol más eficaz de la evangelización y cristianización de las razas nativas y mestizas. La predicación a la que no pudo dedicarse como hubiera querido, la ejercitó de un modo excelente con el ejemplo de su vida, con el testimonio de su cristianismo, y como un auténtico profeta de la guadalupana para el pueblo mexicano en gestación (Perea, 2001).

\section{Cine sonoro: Escuchar las palabras de la amorosa madre}

En la década de los años treinta inició la era del sonido y los públicos analfabetas se desbordaron al cine ávidos de nuevas historias y temáticas, por lo que los empresarios, además de la utilización del adelanto técnico que significaba oír por primera vez las voces por mucho tiempo silenciadas, tenían una nueva oportunidad de crear y construir géneros y temas. 
La Guadalupana haría su aparición en los primeros años de la década con Alma de América ${ }^{11}$ (1931), de Adolfo Bustamante Moreno. Un filme que utilizó la sonorización con música de fondo y un narrador que ilustraba algunos momentos históricos de la aparición de la Virgen; mostrándola madre de los mexicanos y hacedora de milagros.

Esta película se conformó en una mezcla de documental y ficción, por lo que se encuentra más cercana a la categoría de película histórica, en la que se manifestaba el fervor guadalupano y la exaltación de figuras políticas, mostrando la historia como un proceso cambiante.

En 1939 se realizó La reina de México, también conocida como Las cuatro apariciones de la Virgen de Guadalupe, dirigida por Fernando Méndez, quien para la filmación fue asesorado por autoridades religiosas, y contó con la participación de Maritza Nieto, Tito Junco y Pedro Galindo.

En esta cinta el realizador Fernando Méndez utilizó música sacra. Terminada la película fue estrenada el 12 de diciembre de 1940, en una historia donde se incluyeron tomas de la basílica y sus alrededores, mientras entre sus exteriores lució el cerro del Tepeyac (Viñas, 2005, p. 429).

Poca información se encuentra sobre ella, pero el tono narrativo utilizado fue de filme histórico como documento, pues se concentró en mostrar las apariciones de la Virgen con inusual apego al mito histórico.

La historia de la cinta se contaba como un flash back a partir de vistas documentales de la Basílica de Guadalupe, cuya historia arquitectónica era narrada en off, y de un baile de concheros en el patio mayor del templo, después de lo cual alguien ponía flores en la tumba de Juan Diego. Mientras tanto, ya no tan en plan documental, el trío de los Galindo llegaba a las puertas de la Basílica y cantaba con fervor "Virgencita milagrosa". Al final de la película, otras vistas documentales mostraban el interior de la Basílica donde 3/4decía el narrador $3 / 4$, el pueblo mexicano honra a la Virgen, llamada la reina de México (García, 1993, p. 140).

\footnotetext{
11 Con respecto a esta película existe una imprecisión histórica del año de su realización, pues a pesar de que Emilio García Riera (1993) se refiera a ella como una producción realizada en 1941 y que Moisés Viñas (2005) repite esta fecha de realización, la película se produjo en 1931 con motivo del Iv Centenario de la aparición de la Virgen de Guadalupe. Una copia se encuentra en Filmoteca de la UNAM, la cual fue revisada para la realización de este trabajo. El filme fue remasterizado en 1941 (quizá por ello la confusión con respecto a la fecha de creación). Tiene un expediente en el Centro de Documentación de la Cineteca Nacional con el número A-02107.
} 
En 1942, La Virgen morena ${ }^{12}$ de Gabriel Soria se consideró una superproducción con un presupuesto de un millón de pesos que permitió construir réplicas de palacios aztecas, la participación de mil extras para recrear el México de 1531, pero sobre todo se convirtió en la representación idílica del indigenismo.

Hasta 1942 la mayor aspiración de un personaje indígena en el cine mexicano era equipararse con el Juan Diego (José Luis Jiménez) que aparecía en La Virgen morena de Gabriel Soria. Así podría decir con voz tipluda "Señora y reina mía", ostentar una breve piocha en su redondo rostro lampiño y bajar apresuradamente los cerros milagrosos con pasitos cortos y diligente (Ayala, 1979, p. 195).

Este filme alcanzó gran éxito, por la representación del mito Guadalupano y los escenarios de la historia, reconstruidos por la investigación en manuscritos y leyendas orales.

He visto la interpretación de Juan Diego de La Virgen morena y puedo asegurar que es la encarnación más fiel, más espiritual y más semejantemente física, a nuestro ideal cristiano de aquel privilegiado indio, que se ha logrado, ni pueda lograrse jamás en la pantalla y recomiendo con todo entusiasmo a todos los fieles, que lo conozcan, lo admiren y lo aplaudan a través de esta genial interpretación (García, 1993, p. 278).

La trama implicaba una historia de amor y conversión. En 1531, el príncipe azteca Tenoch rapta a Blanca, la hija del virrey, para evitar los abusos de un capitán contra los nativos. Tenoch hiere a un indio converso, Bernardino, tío de Juan Diego, a quien se le aparece la Virgen de Guadalupe, pero el obispo no lo cree. El capitán ataca el palacio de Tenoch y descubre que Blanca se ha enamorado del indígena. La Virgen se aparece por tercera vez, sana a Bernardino y deja su imagen en el ayate de Juan Diego. Eso convence a todos de su existencia y Tenoch se convierte.

La Virgen morena fue fruto del esfuerzo del jesuita Carlos María de Heredia, quien durante el sexenio de Manuel Ávila Camacho fue reconocido como literato y autor de opúsculos. El sacerdote llevó a cabo una serie de declaraciones en donde manifestaba sus criterios acerca de la necesidad de un milagro para unir a grupos sociales que convivían en un teca Nacional, bajo el número A-04164, que incluye incluso críticas cinematográficas extranjeras. 
mismo espacio, realizando un paralelismo entre la época de la conquista en México -con españoles e indígenas- y el conflicto que se encontraba presente en la Yugoslavia de los años cuarenta.

Este filme visualizaba a la historia como experimentación, pues aportaba una estricta reconstrucción histórica de los acontecimientos narrados, pero con narrativas en donde interactuaban personajes ficticios.

El clímax tiene lugar en una escena de fuerte sabor teatral, en la que la impresión milagrosa en la saya del indio se revela en presencia de todo el reparto, especialmente aquellos que interpretan a las autoridades (el virrey a la cabeza). La única innovación aportada al asunto es la enfermedad del tío de Juan Diego, habitualmente imprecisa y de causas naturales: aquí es producida por un flechazo envenenado de Témoc (sic.) ansioso de vengar la dedicación proselitista del indio a la propagación de la fe cristiana (De España, 2013, p. 33)

En 1942 también se concretó La Virgen que forjó una patria, dirigida por Julio Bracho y fotografiada por Gabriel Figueroa; una mirada sobre la lucha de la Independencia de México que articula la formación del Estado mexicano y la fe católica Guadalupana.

El haber tomado el cura Hidalgo, de la iglesia de Atotonilco, Guanajuato, el estandarte con la imagen guadalupana, no fue una casualidad sino un acto bien meditado que dio a la insurgencia una bandera político-religiosa por ser ya en esos años, la Virgen de Guadalupe el símbolo de la unidad religiosa, el emblema nacionalista por excelencia concebido por México y para México en dación directa de la divinidad, sin intervención de la autoridad española. Representaba lo más santo y lo más genuino de la patria mexicana y además era el culto que más raíces había echado en la masa del pueblo. Por esa razón Hidalgo lo enarboló en aquellos años como su símbolo, como lo harían un siglo después, las huestes de Zapata al lanzarse a reclamar tierra y libertad (De la Torre, 1982, p. 14).

La película abarcó tres líneas argumentales: el inicio de la lucha independentista con licencias históricas a propósito del relato original, que patentiza la devoción de Hidalgo a la Guadalupana, subrayando la noción de identidad y mexicanidad; la recreación del periodo posterior a la conquista, totalmente inverosímil e imaginativo, aunque con respeto por las culturas originales, casi de forma documental; y por último, el abordaje de las apariciones de la Virgen dentro del ámbito religioso. 
Estos argumentos al integrarse formaban una narrativa novedosa que tenía como unidad el mito Guadalupano, y que podría encasillarse según los cánones de Rosenstone en filme de experimentación.

La intriga de La Virgen que forjó una patria reúne todos los elementos colaterales de la leyenda: la insoportable opresión de los indios, la bondad de los frailes, la maldad de los encomenderos, todo ello enmarcado en los acontecimientos de 1810, con el cura Hidalgo lanzándose a la rebelión a los gritos de: Viva la Virgen de Guadalupe (De España, 2013, p. 32).

En 1945, la productora Films Mundial estrenó Virgen Morena, Emperatriz de América, sin datos del director, con el tema de la coronación de la Guadalupana como Reina de México que incluía un mensaje del Papa Pío XII y un discurso del cardenal Rodrigo R. Villanueva, delegado del Sumo Pontífice. Por su manufactura en tono documental y por la existencia de un narrador expositor, esta película puede ser asignada al rubro de película histórica, según la catalogación de Rosenstone.

El 12 de octubre de 1895 la bendita imagen de la santísima Virgen fue coronada por decreto del santo padre, León XIII, y el 12 de octubre de 1945, cincuentenario de la coronación, su santidad Pío XII en su célebre radio mensaje a los mexicanos le aplicó el título de Emperatriz de las Américas: 'Feliz oportunidad ésta del 50 aniversario del Patronato de María Santísima de Guadalupe sobre toda la América latina, que tanto bien ha producido entre los pueblos del continente, para alentaros en vuestras manifestaciones de mutuo amor y de devoción a la que es madre de vida y fuente de gracia. Primero madre y patrona de México, luego de América y de Filipinas: el sentido histórico de su mensaje iba cobrando así plenitud, mientras abría sus brazos a todos los horizontes en un anhelo universal de amor. ¡Salve madre de América! celestial misionera del nuevo mundo, que desde el Santuario del Tepeyac has sido, durante más de cuatro siglos madre y maestra en la fe de los pueblos de América. Sé también su amparo y sálvalos oh inmaculada María; asiste a sus gobernantes, infunde nuevo celo a sus prelados, aumenta las virtudes en el clero; y conserva siempre la fe en el pueblo' (Devocionario Católico, 2011).

También en 1945, en la víspera del día de la guadalupana, se estrenó La sonrisa de la Virgen, producida por los hermanos Rodríguez, donde participó la pequeña María Gracia, quien con su tierna actuación conmo- 
vió al público. En una historia de inocencia, la niña habla con la Virgen, para quien su única petición es no ir más al colegio. La sinopsis describe:

La niña María vive en la granja de su abuela y es amiga de todos los animales y del pastor Anselmo. La abuela la lleva a la escuela y ella se siente prisionera y escapa. Se pierde en el cerro, pero Anselmo la encuentra. Entonces pide a la Virgen de Guadalupe que le haga el milagro de no volver a la escuela y al día siguiente cree que así ha sucedido, pero sólo es el día de descanso. Por eso trepa al altar para que la Virgen la escuche bien, pero se detiene ante un crucifijo, pues compadecida le quiere quitar los clavos de las manos. La Virgen sonríe a la niña y ella sale. Irá con gusto a la escuela y ese será el milagro. (Viñas, 2005, p. 479).

Debido a su tratamiento, esta película puede ser clasificada como historia dramatizada, pues se crea una narrativa de ficción a propósito de la mitología acerca de la Virgen como creadora de milagros.

En 1960, el actor y director Julián Soler realizó Las rosas del milagro, considerada una de las mejores producciones de su época debido a la utilización de un novedoso adelanto técnico: la pantalla panorámica a color, conformando un espectáculo que recreó el imperio de Moctezuma y las apariciones de la Guadalupana.

Esta realización fue elogiada por la crítica, incluyendo al cardenal José Garibi Rivera, arzobispo de Guadalajara, quien la recomendó ampliamente. En el filme se cuenta la historia de la princesa azteca Citlalli, quien está enamorada del huejotzinga Nonoatzin, enemigo de su padre, el emperador Moctezuma, quien al saberlo hace la guerra y derrota a los de su casta. Nonoatzin es sacrificado a la diosa Coatlicue y Citlalli se envenena. Al llegar los españoles, destruyen los teocallis. Años después, la Virgen se aparece a Juan Diego, a quien el obispo Zumárraga pide pruebas del milagro. En la tilma del indio, unas rosas pintan la imagen de la Virgen. El diálogo de la película afirmaba:

Señor, hice lo que me ordenaste, que fuera a decir a mi ama, la señora del cielo, santa María, preciosa madre de Dios, que pedías una señal para poder creerme que le has de hacer el templo donde ella te pide que lo erijas; y además le dije que yo te había dado mi palabra de traerte alguna señal y prueba, que me encargaste, de su voluntad. Condescendió a tu recado y acogió benignamente lo que pides, alguna señal y prueba para que se cumpla su voluntad. Hoy muy temprano me mandó que otra vez viniera a verte; le pedía la señal para que me cre- 
yeras, según me había dicho que me la daría; y al punto lo cumplió; me despachó a la cumbre del cerrillo, donde antes yo la viera, a que fuese a cortar varias rosas de Castilla. Después que fui a cortarlas, las traje abajo; las cogió en su mano y de nuevo las echó en mi regazo, para que te las trajera y a ti en persona te las diera (Soler, 1960).

En esta producción se logran visualizar rasgos de una hibridación de dos categorías propuestas por Rosenstone: la historia dramatizada y como experimentación; sin embargo, en la trama existe una propuesta narrativa novedosa por lo que encasillará en esta última.

En 1965 Federico Curiel preparó La Virgen de Guadalupe y sus retablos, también conocida como Retablos de la Guadalupana, la cual se encontraba dividida en dos historias: la primera, Los novios, con las actuaciones de Julio Alemán, Marta Romero, Andrea Palma y Tito Junco, narraba la historia de encuentros y desencuentros de una pareja que finalmente quedaba unida por el milagro de la Virgen; y la segunda, con el título El vicio y las interpretaciones de Enrique Lucero, Ethel Castillo y el niño Julián Bravo, un alcohólico después de varias recaídas jura y reza a la Virgen para que salve a su hijo, quien se encontraba grave en el hospital por su descuido.

La crítica fue poco alentadora hacia la cinta, aunque siguió el modelo de historia dramatizada, pues parte de dos historias con personajes individualizados, cuyo leit motiv era el milagro que la Virgen obraba sobre ellos.

Federico Curiel probó cierta competencia en el cine de acción, pero me temo que ni él ni ningún otro director hubieran podido salvar este doble melodrama atribulado por una doble calamidad: la indiferencia en la producción y el exceso de la mochería en las historias. Pese a su reclamo religioso, la cinta no interesó a su público humilde de la capital (García, 1993, pp. 299-300).

En 1976, Alfredo Salazar llevó a cabo La Virgen de Guadalupe, adaptación de La Virgen Morena de 1942. Siguiendo la categorización de Rosenstone, ésta puede ser enumerada en la historia como drama, pues partía del argumento de su antecesora y profundizaba en la vida de Juan Diego, encarnado por Fernando Allende:

Descendiente de los chichimecas, nació en Cuautitlán en el año 1474. A los cincuenta años [...] escuchó por primera vez la palabra de Dios, de labios de los misioneros españoles. Dejó su creencia pasada y se 
convirtió al cristianismo recibiendo el sacramento del bautismo. Sin realizar nada extraordinario, dio ejemplo con su vida y sus palabras; fue un hombre humilde, sencillo, piadoso, bondadoso y apostólico [...] La santísima Virgen se le apareció en el cerro del Tepeyac, convirtiéndose en el instrumento fiel, transmisor del mensaje de la Virgen al señor obispo Juan de Zumárraga. Vivió de modo callado y escondido durante diez y siete años al lado de la Ermita de Nuestra Señora construida en 1531. Murió en el año 1548. Sus restos están en la "Capilla antigua" llamada "Parroquia de indios" al pie del cerrito (Baduí, 1992, p. 5).

También en esa década se realizó Nuevo mundo (1976) de Gabriel Retes, la cual se convirtió en un filme controvertido e innovador al debatir acerca de la existencia del mito guadalupano, pero sin nombrarlo explícitamente. El argumento narraba la historia treinta años después de la conquista de Tenochtitlán en donde un evangelizador jesuita, para lograr la unión entre conquistadores y conquistados, inventa la imagen de una Virgen que logre, además de esta encomienda, el sometimiento de los indios. La película fue censurada, enlatada y por sus características en relación con la historia podría ser catalogada como experimental.

En la historia, los conquistadores enfrentan un inminente levantamiento indígena por su rechazo a la evangelización. Entonces fray Pedro Francisco de Cañas convence al pintor indígena Manuel Ortiz para que invente una virgen empleando a una nativa como modelo, y que presente la obra al pueblo proclamándola como una aparición y, por tanto, como un milagro (Ponce y Vértiz, 2002). ${ }^{13}$

\section{Fin del recorrido: ¿Una Virgen posmoderna?}

Sin duda, la Virgen de Guadalupe está vigente en diversos ámbitos, es objeto de estudio en la sociología de las religiones, la psicología de masas, la antropología social y en estudios teológicos. Sin embargo, en la llamada posmodernidad que proclama el fin de las ideologías, apocalipsis de la historia, abandono de las visiones totalizadoras a partir de las cuales la narratividad sirve para explicar el comportamiento humano, así como la multiplicidad de versiones y el debilitamiento del carácter absoluto del pensamiento, surge la pregunta: ¿qué sucede con el culto guadalupano?

\footnotetext{
13 La película cuenta con un completo expediente en el Centro de Documentación de la Cineteca Nacional, bajo el número A-01022.
} 
Más allá de las creencias religiosas y de las opiniones históricas, la Virgen de Guadalupe expresa, para muchos mexicanos, una ambivalencia: reina del mundo y devoción del hogar, es la prestigiosa identidad universal de la nación, lo mismo que una zona de la intimidad que se prefiere no discutir con extraños (Domínguez, 2011).

¿La posmodernidad ha alcanzado a la Virgen de Guadalupe? ¿Sigue presente la fe en la imagen? ¿Se continúan contando historias acerca del milagro de sus apariciones? En el cine mexicano, la Virgen de Guadalupe ha sido motivo de inspiración para que la industria fílmica realice una producción en cada década desde 1910 y, a pesar de que siempre ha existido un debate acerca del origen divino de la imagen, en la época posmoderna ha reaparecido la Guadalupana en tres cintas con facetas actuales: El pueblo mexicano que camina (1995) de Juan Francisco Urrusti, Guadalupe (2006) de Santiago Parra y Morenita, el escándalo (2009) de Alan Jonsson.

La primera es una película de no ficción 3/4por su estructura de reportaje, en la clasificación realizada por Rosenstone es un filme histórico documental $3 / 4$ que forma parte del Archivo Etnográfico Audiovisual del Instituto Nacional Indigenista, ${ }^{14}$ en donde personajes intelectuales, deportistas, líderes y religiosos expresan su opinión sobre el mito guadalupano. "Además se registran peregrinaciones a la Basílica y fenómenos aparentemente milagrosos en diversos sitios. Se incluyen también fragmentos de películas sobre las apariciones de la Virgen al indígena Juan Diego y escenas de veneración e imploración" (Viñas, 2005, p. 412).

En Guadalupe (2006) de Santiago Parra se narra la historia de Mercedes y José María (hermanos), que crecen en España con su abuela, debido a la pérdida de sus padres, a quienes nunca conocieron. Con el fallecimiento de la anciana descubren un cuadro de la Virgen de Guadalupe frente a su lecho de muerte. Intrigados por la imagen emprenden una búsqueda histórica y arqueológica que los llevará a México. Así, lo que originalmente empezó como un estudio acerca de la Virgen, se transformará en un hallazgo íntimo que los hará desafiar su pasado y presente.

En el filme, partiendo de las apariciones de la Guadalupana, se evidencia el poder de la imagen después de quinientos años. Y para subrayar la El Instituto Nacional Indigenista produjo 48 películas entre 1977 y 1995, época en que se consolidó el Archivo Etnográfico Audiovisual con figuras como Luis Mandoki, Henner Hofmann, Ludwik Margules, Juan Carlos Colín y Juan Francisco Urrusti. La película tiene un pequeño expediente hemerográfico en el Centro de Documentación de la Cineteca Nacional bajo el número A-03896. 
polémica en torno al milagro y a la falta de fe en la época actual, la página oficial de la película sintetiza su trascendencia para el pueblo mexicano:

Lee lo que la ciencia ha descubierto en el manto de la Virgen en Guadalupe: 1. Estudios oftalmológicos realizados a los ojos de María han detectado que, al acercarles luz, la retina se contrae y al retirar la luz, se vuelve a dilatar, exactamente como ocurre en un ojo vivo. 2. La temperatura de la fibra de maguey con que está construida la tilma mantiene una temperatura constante de 36.6 grados, la misma que el cuerpo de una persona viva. 3. Uno de los médicos que analizó la tilma colocó su estetoscopio debajo de la cinta que María posee (señal de que está en cinta) y escuchó latidos que rítmicamente se repiten a 115 pulsaciones por minuto, igual que un bebé en el vientre materno. 4. No se ha descubierto ningún rastro de pintura en la tela. De hecho, a una distancia de 10 centímetros de la imagen, sólo se ve la tela de maguey en crudo: los colores desaparecen. Estudios científicos no logran descubrir el origen de la coloración que forma la imagen, ni la forma en que la misma fue pintada. No se detectan rastros de pinceladas ni de otra técnica de pintura conocida. Los científicos de la NASA afirmaron que el material que origina los colores no es ninguno de los elementos conocidos en la tierra. 5. Se ha hecho pasar un rayo láser en forma lateral sobre la tela, detectándose que la coloración de la misma no está ni en el anverso ni en el reverso, sino que los colores flotan a una distancia de tres décimas de milímetro sobre el tejido, sin tocarlo. ¿Te parece sorprendente? 6. La fibra de maguey que constituye la tela de la imagen, no puede perdurar más que 20 o 30 años. Hace varios siglos se pintó una réplica de la imagen en una tela de fibra de maguey similar, y la misma se desintegró después de varias décadas. Mientras tanto, a casi 500 años del milagro, la imagen de María sigue tan firme como el primer día. La ciencia no se explica el origen de la incorruptibilidad de la tela. 7. En el año 1791 se vuelca accidentalmente ácido muriático en el lado superior derecho de la tela. En un lapso de 30 días, sin tratamiento alguno, se reconstituye milagrosamente el tejido dañado. 8. Las estrellas visibles en el manto de María reflejan la exacta configuración y posición que el cielo de México presentaba en el día en que se produjo el milagro (Oficial, 2011).

Esta cinta puede ser referida, según las categorías de Rosenstone, como un cine que visualiza la historia como experimentación, al realizar una mezcla entre estilos y formas narrativas, aunado a la mirada personal de los personajes acerca del mito Guadalupano. 
El último filme es Morenita, el escándalo (2009, Alan Jonsson). La crítica destacó, además del título, el cartel 3/4nunca se había utilizado la imagen de la Virgen de Guadalupe mezclada con el narcotráfico $3 / 4$ en donde la figura religiosa, aparece delineada con polvo de la droga con lujo de detalles; bajo la misma, un billete enrollado simboliza la corrupción y el lavado de dinero del narcotráfico, o una forma de ingerir la cocaína, además aparecen casquillos de bala.

La película cuenta la historia de Mateo, un instructor de palomas mensajeras, quien vende un lote a Aurelio, alias "El Pinto", narcotraficante del cártel de Tijuana, quien las utiliza para transportar cocaína. Sin embargo, no funcionan para la encomienda y "El Pinto" tortura a Mateo para que le devuelva el dinero. Desesperado, Mateo secuestra la imagen de la Guadalupana de la Basílica para pedir rescate, lo que acarrea un caos espiritual en el país.

En el filme además de la discusión en torno al tratamiento que hace del tema religioso y la espiritualidad del pueblo mexicano, plantea una diversificación de miradas sobre la imagen de la Virgen como símbolo religioso, proponiendo una línea narrativa novedosa y experimental, al asociar el ícono de la Guadalupana junto a una problemática mexicana, como lo es el narcotráfico, por lo que este filme será catalogado como historia experimental.

La justeza del sacrilegio parece impregnarlo y justificarlo todo, tanto el absurdo voluntario como el involuntario, hasta el infinito del ridículo y más allá, multiplicando sacrilegios de manera angustiosa e incontinente, aunque sin tropezar eso sí con chantajes emotivos ni sentimentalismos fáciles. Sacrilegio ñoño contra la infeliz melancolía mexicana actual en ese cuadro inicial de ñoña felicidad familiarista disneyana con palomitas (Ayala, 2014, p. 176).

\section{A manera de conclusión}

Morenita, el escándalo cierra una década en el cine mexicano manifestando tradición y fe por la Virgen morena, quien en la actualidad se revela como madre amorosa del mexicano, para quien la imagen es más que un ícono de devoción, es parte integral de su historia e identidad.

Para algunos, la importancia de la imagen radica en los mensajes de sus apariciones, ocurridas entre el 9 y el 12 de diciembre de 1531, y es esta alocución y el milagro de su aparición 3/4incluida la figura del indio Juan Diego3/4 lo que se repite en el ámbito cinematográfico desde 1917 con un discurso que ha cambiado en su forma, pero no en contenido. 
De las diecinueve películas referidas en este trabajo, cinco pueden ser catalogadas, según la propuesta de Robert Rosenstone, dentro de la categoría de historia dramatizada, la cual tiene como principal característica que se refiere a dramas situados en el pasado con algunas "licencias históricas".

Seis realizaciones se encuentran en el rubro experimental, el cual comprende aquellos filmes que intentan visualizar la historia desde la experimentación, teniendo, entre otras características, alejarse del sentido estético de la industria mezclando y creando nuevas formas narrativas para abordar acontecimientos pasados. Finalmente, ocho de ellas se acercan a acontecimientos históricos partiendo de un ámbito más cercano al documental en términos de lo que se denomina película histórica, entendida como aquella en la que aparecen personajes y eventos que pueden ser documentados, de estilo más monográfico y, aunque pareciera más veraz, se enfrenta al problema de las fuentes históricas utilizadas.

Hay que subrayar además que la narrativa más recurrente en el mito Guadalupano es el milagro de sus apariciones; es decir, que sin importar las relaciones que se tienden entre cine e historia, una parte del argumento abordará este pasaje, ya sea como parte del relato o como referencia audiovisual, pero estas alusiones se convertirán en el cimiento cinematográfico del personaje de la uadalupana.

Otro elemento destacable de este estudio es que la clasificación de las películas en razón de la relación entre cine e historia, no sólo obedecen a su contenido sino exploran el momento histórico de su realización, articulando un discurso de producción histórico.

En los primeros seis filmes del periodo silente, se alude a la relación cine/ historia sobre la guadalupana, a través de un tratamiento de historia dramatizada y película histórica, pues son años de conformación en la industria nacional, que acuña géneros e inventa temáticas, y a través de estas dos vías permite una comprensión del mito guadalupano que parte de relatos con licencias históricas o más cercanas al documental.

En la Época de Oro, la relación entre cine/historia, en la visualización del personaje guadalupano, permite una diversificación en el tratamiento de sus historias al aparecer filmes experimentales que permiten articular un discurso innovador que alterna en las historias -milagro de las apariciones y miradas en pasado y presente-, recreaciones temporales y superproducción, lo que posibilita nuevas narrativas.

Dos etapas más permitirán consideraciones sobre el personaje cinematográfico de la guadalupana. La primera de 1950 a 1980, periodo de crisis en la industria del cine, que ratifica la pervivencia del personaje con un tratamiento híbrido -entre la historia dramatizada y la experimenta- 
ción-, acompañando a la industria en una búsqueda de alternativas para subsistir, regresando a tratamientos de éxito en el pasado, a la par que el cine independiente comenzaba a abrirse camino en los márgenes de la industria cinematográfica nacional.

Y finalmente, las realizaciones de los inicios del siglo XXI, que abre el panorama de experimentación y de nostalgia 3/4película histórica documental $3 / 4$ en torno al personaje de la Virgen morena, en donde además de la relación entre el cine/historia en sus relatos, la innovación en cuanto a tramas y subtramas exploradas -investigación científica, narcotráfico y violencia-, articula otro abordaje con narrativas fragmentadas.

A manera de cierre, se puede afirmar que la Virgen de Guadalupe se ha conformado como personaje nexo entre la historia y el cine mexicano, consolidándose como emblema de consuelo ante la adversidad e insignia de la religión católica mexicana, cuya presencia se hace patente en la vida cotidiana: en la medalla que pende del cuello, en los altares de talleres y fábricas; amorosa en la cabecera de las camas; vigilante en las casas, calles, caminos y transportes; providente en los mercados y espacios públicos; compañera en las luchas cívicas; bautizante en nombres de habitantes y poblados; estampita confidente en los bolsillos; alivio y fortaleza en las penas, y hasta testigo de las fechorías, pues es emblema que cobija la identidad de un México que sigue venerando a la Virgen que forjó una Patria.

\section{Archivos}

Archivos Centro de Documentación. Cineteca Nacional. Expedientes hemerográficos.

\section{Referencias bibliográficas}

Ayala, J. (1979)

La aventura del cine mexicano. Ciudad de México: Cine club Era. Ayala, J. (2014)

La justeza del cine mexicano. México: Universidad Nacional Autónoma de México.

Béjar R. y Rosales H., coords. (1999)

La identidad nacional mexicana como problema político y cultural. Cuernavaca: Universidad Nacional Autónoma de México.

Baduí, J. (1992)

Nihil Obstat. México: Jus.

Bornstein, A. (1991)

El pasado a 24 imágenes por segundo: Reflexiones sobre la utilidad del cine histórico. Cuadernos de historia moderna No. 12. Madrid: Universidad Complutense. 
Caparrós, J. (s/f)

Nueva propuesta de clasificación de películas históricas. Cine Historia. http://www.cinehistoria.com/propuesta_de_clasificacion_de_peliculas_historicas.pdf

Centro de Estudios Guadalupanos (1980)

Documentario guadalupano 1531-1768. Puebla: Centro de Estudios Guadalupanos.

Dávalos, F. y Flores C. (Comps.) (2013)

Historia del cine mexicano (1896-1929). Edición facsimilar de las crónicas de José María Sánchez García. México: Universidad Nacional Autónoma de México.

De España, R. (2013)

La conquista de México en el cine: El caso de la Virgen de Guadalupe. Boletín Americanista, LXIII/1, 66, pp. 29-49.

De la Maza, F. (1953)

El guadalupanismo mexicano. México: Porrúa y Obregón.

De la Torre, E. (1982)

En torno al Guadalupanismo. México: Porrúa.

De los Reyes, A. (1977)

80 años de cine en México. México: Universidad Nacional Autónoma de México, Difusión Cultural, Serie Imágenes No. 2.

De los Reyes, A. (1993)

Cine y sociedad en México, 1896-1930. Bajo el cielo de México. Volumen II (1920-1924). México: Universidad Nacional Autónoma de MéxiCo , Instituto de Investigaciones Estéticas.

De los Reyes, A. (2000)

Filmografía del cine mudo mexicano. Volumen III 1924-1931. México: Dirección de Actividades Cinematográficas, Universidad Nacional Autónoma de México.

De los Reyes, A. (2011)

Medio siglo de cine mexicano (1896-1947). México: Trillas.

De Orellana, M. (1991)

La mirada circular. El cine norteamericano de la revolución mexicana 1911-1917. México: Artes de México.

Devocionario Católico. (2011)

Nuestra Señora de Guadalupe. Historia de las apariciones. Devocionario Católico. Recuperado de http://www.devocionario.com/maria/ guadalupe_3.html

Domínguez, C. (2011)

La Virgen de Guadalupe: Imagen y tradición de David A. Brading. Letras Libres. Recuperado de http://www.letraslibres.com/index. php?art $=729$ 
Florescano, E. (1999)

Memoria indígena. México: Taurus.

García R., E. (1994)

Historia documental del cine mexicano. Tomos 2, 3, 4, 5, 8 y 12. Guadalajara: Consejo Nacional para la Cultura y las Artes, Universidad de Guadalajara. (Tomo 2, Primera reimpresión 1993); (Tomo 3, Primera reimpresión 1993).(Tomo 4, 1993).(Tomo 5, 1993).(Tomo 8, 1993). (Tomo 12, 1993).

Garrido, J.A. (1990)

Minorías en el cine: la etnia gitana en la pantalla. Barcelona: Universitat de Barcelona.

Halbwachs, M. (1950)

La mémoire collective. París: Les Presses Universitaires de France.

Kracauer, S. (1947)

De Caligari a Hitler. Barcelona: Paidós.

Lozano, J. (2018)

Rasgos del cine histórico. Reflexión desde el cine colombiano. Revista Comunicación y Sociedad No. 31. Enero-abril 2018. Recuperado de http://www.comunicacionysociedad.cucsh.udg.mx/index.php/comsoc/article/view/6577/5940

Molina, L. (2010)

Fe mexicana y la Virgen María de Guadalupe en el cine. Recuperado el 30 de septiembre de $2010 \mathrm{de}$ http://mexicodice.com/?tag=evangelistasde-la-guadalupana

Oficial (2011)

Página oficial de la película Guadalupe. Recuperado el 6 de enero de 2011 de http://proyectos.direccionvirtual.com.mx/guadalupe/ (Enlace roto)

Páez, D., Valencia, J., N., Herranz, K., González, J.L. (2000) Identidad, comunicación y memoria colectiva en Alberto, R. R. (Ed.), Memoria Colectiva e Identidad Nacional. España: Biblioteca Nueva.

Películas del cine mexicano (2011)

Películas del cine mexicano. Recuperado de http://web.archive.org/ web/20180522224010/http://cinemexicano.mty.itesm.mx/peliculas/ tepeyac.html

Perea, J. (2001)

El observador de la actualidad. Periodismo católico para la familia de hoy. http://www.mercaba.org/FICHAS/Devociones/el_observador_9_ diciembre_2001_no_335.htm

Ponce A. y Columba Vértiz (2002)

Nuevo mundo. Una película enlatada desde 1977. La Virgen inventada... y censurada. Revista Proceso, México, 8 septiembre 2002. 
Rosenstone, R. (1997)

El pasado en imágenes. El desafío del cine a nuestra idea de la historia. Madrid: Ariel.

Rosenstone, R. (2014)

La historia en el cine: el cine sobre la Historia. España: Rialp.

Senado (2010)

XII Ideas políticas y proclamas. Recuperado de https://archivos.juridicas.unam.mx/www/bjv/libros/6/2709/24.pdf

Vaca, A. (2016)

Los cristeros y la jerarquía: variaciones sobre un mismo tema. Recuperado de http://www.scielo.org.mx/scielo.php?script=sci_arttext\&pi $\mathrm{d}=\mathrm{S} 1665-05652016000200121$

Viñas, M. (2005)

Índice general del cine mexicano. México: Consejo Nacional para la Cultura y las Artes.

\section{Filmografía:}

Ramos, J. M. y González, C. (directores); Ramos, J.M. y González C. (guionistas) (1917)

Tepeyac. México: Films Colonial.

Wright, G. (director); Wright, G. (guionista) (1918)

La Virgen de Guadalupe. México: Geo D. Wright.

Anónimo (director); Anónimo (guionista) (1920)

Bodas de plata de la Virgen de Guadalupe. México: Martínez y Compañía.

Anónimo (director); Anónimo (guionista) (1922)

Documental Basílica y sus alrededores. México: Hallman.

Ruiz, v. (director); Anónimo (guionista) (1924)

El pueblo mexicano acude fervoroso a rendir culto a la Virgen india.

México: Revista Cinematográfica El Universal.

Earle, W. (director); Earle, B.T. (guionista) (1925)

El milagro de la guadalupana. México: Amex films.

Bustamante, A. (director); Lerrón, A. (guionista) (1931)

Alma de América. México: Mexicana Elaboradora.

Méndez, F. (director); Méndez, F. y Flores, C. (guionistas) (1939)

La reina de México. México: Iracheta y Elvira.

Soria, G. (director); Soria G. y Santander A. (guionistas) (1942)

La Virgen morena. México: Alberto Santander y Gabriel Soria.

Bracho, J. (director); Bracho, J. (guionista) (1942)

La Virgen que forjó una patria. México: Mundiales, Emilio Gómez Muriel. 
Anónimo (director); Anónimo (guionista) (1945)

Virgen morena. Emperatriz de América. México: Films Mundial.

Rodríguez, R. (director); García Travesí R. y Rodríguez, R. (guionistas)

(1945)

La sonrisa de la Virgen. México: Rodríguez.

Soler, J. (director); Patiño Gómez, A. (guionista) (1960)

Las rosas del milagro. México: F. México.

Curiel, F. (director); Torres Gaytán, R. (1965)

La Virgen de Guadalupe y sus retablos. México: Fílmica Vergara Cinecomisiones.

Salazar, A. (director); Salazar, A. (guionista) (1976)

La Virgen de Guadalupe. México: C. Calderón.

Retes, G. (director); Miret, P. (guionista) (1976)

Nuevo mundo. México: Corporación Nacional Cinematográfica.

Urrusti, J. (director); Piñó, A. (guionista) (1995)

El pueblo mexicano que camina. México: Instituto Nacional Indigenista.

Parra, S. (director); Gutiérrez de Picazo, T. (guionista) (2006)

Guadalupe. México: Dos Corazones Films.

Jonsson, A. (director); Jonsson, A. y Oakes, A. (guionistas) (2009)

Morenita, el escándalo. México: Arte Mecánica Producciones, Esfera

Films Entertainment y Fidecine. 